\title{
3311 エネルギ収支に着目した新しい最適制御
}

\section{A Newly Developed Optimal Control Theory Based on Energy Equation}

\author{
○正 福島 直人 (東工大), 正 萩原 一郎（東工大）
}

Naoto FUKUSHIMA, Tokyo Institute of Technology, 2-12-1, Ookayama, Meguro, Tokyo 152-8552

Ichiro HAGIWARA, Tokyo Institute of Technology, 2-12-1, Ookayama, Meguro, Tokyo 152-8552

\begin{abstract}
A Newly developed optimal control theory based on energy equation is introduced. The point of this theory is to utilize the self solving mechanism which is included in closed loop systems as a general characteristic. For this purpose, the energy equation of controlled system is focused on. In this method, the functional consists of total energy of controlled system, performance function and energy function. This energy function is described by energy flow which is transmitted from controller to controlled system. Being shown as a first-order expression concerning control variables, the functional is able to induce the optimal system equation from the condition which minimizes the functional. Then optimal control is realized by putting the optimal equation into a closed loop system without solving the equation. This method is useful for nonlinear mechanical control systems because real time control can be realized by this method.
\end{abstract}

Key Words: Optimal Control, Energy Equation, Closed Loop System, Mechanical System.

\section{1. まえがき}

約 50 年前にポントリャーギンらによって導かれた最大原 理 ${ }^{(1)}$ に端を発する最適制御理論はその後のシステム制御工 学発展に大きな影響を与えた ${ }^{(2)}$.しかし, 例えばここ 20 年 来進展が著しいロボットなどの機械力学系システムの実時 間制御ではこの理論は使いづらくそれほど効力を発揮して いない.

この要因は非線形微分方程式を 2 点境界値問題として解析 的に解くことの困難さにあると思われる.この“解析的”と いう条件を取り去れば, 多くの非線形制御問題はオフライン による繰り返し計算により初期值に依存した開ループ形の 数值解が得られる.しかし， ロボットや車の運動制御など多 くの機械力学系の実時間最適制御では，一般に有限評価区間 が時間とともに移動するような評価関数を用いなければな らず，この場合には msec オーダーの制御周期毎に前記繰り 返し計算が必要となって制御装置に与える演算負荷が莫大 になり現在の最先端のハードウェア技術をもってしても実 現は困難である。これが非線形最適制御問題の解析解(これ により実時間制御が可能になる)が必要とされる背景であり， 従来の最適制御理論がその適用を阻まれている壁である。

このような現実に対して, 従来の延長線上にない抜本的な 解決策を探る必要があると考え既に新しい手法を提案して いる(3). 本論文はこの手法について，新しく“閉ループ系の 特性”という視点から解釈を加えてその特徴を明確にしたも のである. 即ち,“閉ループ系は本来，ハードウエアである 制御対象の運動と制御則と称するソフトウエアで記述され た制御対象のあるべき運動との連立微分方程式を実時間で 解いている”という事実を前面に出した制御理論であり，こ の理論により前述の壁を打開できることを示す.さらにこの 理論を具体的な問題に適用した場合の有用性を示す。

\section{2. 新しい最適制御理論の試み}

2. 1 従来の最適制御理論の概要 従来の最適制御則を求め る手順の概要を述べれば，最小化すべき評価関数の被積分関 数に付帯条件として制御対象の状態方程式の右辺と随伴変 数の積を加えてこれをハミルトニアンHとし，このHを制御変 数いで偏微分したものをゼロと置いたときこれを満たすいが 最適制御則になるということになるう ${ }^{(4)}$.ここで求まる制御
則には随伴変数が含まれているため, 結呞随伴変数について の微分方程式も解かねばならず，最適制御則を解析的に導く ことは容易ではない，そのため様々な研究がなされてはいる が，依然として前述の実時間最適制御問題への適用は大きな 課題である ${ }^{(5)}$.この解決策として次節のような微分方程式を 解かなくても解析解が求まる制御理論を提案している.

\section{2 エネルギ収支に着目した新しい最適制御理論の概要}

一般的に最適制御では制御則山を計算するのに制御対象の出 力を用いるため図1のような閉ループ系を構成する。ここに 紹介する理論はこのような閉ループ系が持づ 自分で微分方 程式を解く性質”を積極的に活用寸るものである. 次節に詳 述するように，評価関数をパワー収支をべースに構成する. 具体的には, 制御入力に関する評価関数を制御装置から制御 対象に伝達されるエネルギとし，これに制御性能を表現する 関数を加え，さらに制御対象の完全なエネルギ収支の式を加 えて全体の評価関数とする。こうするとこの評価関数を最小 化する条件から新しくu を入力とし q を出力とする微分方程 式が導かれ，この逆特性を閉ループに組み込むことで微分方 程式を解かずに最適制御が実現できる。この手法は制御対象 が線形・非線形を問わず適用できるため, 主として機械力学 系システムの比較的広範囲の実時間最適制御問題に適用で きる。

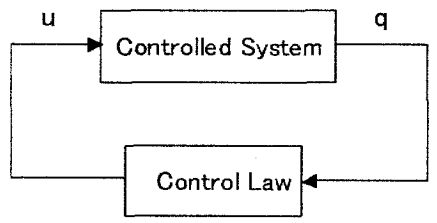

Fig. 1 Block Diagram of Optimal Control System

\section{3. なぜ微分方程式を解かなくてよいのか 上記をもう}

少し詳細に説明する。制御対象のパワー収支式は，式(1)に 示すようにシステムの各自由度每の運動方程式をベクトル 表示しこれに速度べクトルを乗じたものである.これを積分 すればエネルギ収支式が得られる。

$$
u^{T} \dot{q}+v^{T} \dot{q}-\ddot{q}^{T} M(q) \dot{q}-d^{T}(q, \dot{q}) \dot{q}-e^{T}(q, z) \dot{q}=0
$$


ここで, d, e, q, u, v, $\mathrm{z} \in \mathrm{R}^{\mathrm{n}}, \mathrm{M} \in \mathrm{R}^{\mathrm{n} \times \mathrm{n}}$ は慣性マトリ クス，nは制御対象の自由度，qは一般化座標，uは制御入力 である. vは力入力の外乱， $\mathrm{z}$ は変位入力の外乱である. $\mathrm{d}$ は コリオリカや遠心力やダンピングカなど， elポテンシャル カである.

上記のシステムに対し, 従来理論に準じ次の評価関数を考 えてみる.

$$
J=\int\left\{g(q, \dot{q}, \ddot{q})+r u^{T} \dot{q}\right\} d t
$$

ここでgは制御性能の評価を与えるスカラー関数であり, $u^{T} \dot{q}$ は制御装置のアクチュエータが制御対象に加えるパワ 一，r恃重み係数で正定値である。一般化座標qとその 1 階, 2 階の導関数の初期値は与えられているものとする．本理論 は実時間制御を対象としているため，有限評価区間を前提と している. 即ち $\mathrm{t}_{0}$ 老制御開始時点， $\mathrm{T}$ を評価時間とすれば評 価区間は $\left[\mathrm{t}_{0}, \mathrm{t}_{0}+\mathrm{T}\right]$ のように表示される.後に明らかになるよ うに，本理論では評価関数は理想システムを求めるためにの み存在するため, 従来の最適制御理論のような 2 点境界值問 題を構成しない，従ってTはシステムが制御されている時間 より大きめに設定すればよくその大きさは制御則に影響し ない。また式 (2) が最小值をもつことは制御対象が受動的(6) であることを利用して容易に証明することができる。

最適制御の必要条件を求めるため次のスカラー関数 L を定義 する。

$$
\begin{aligned}
L= & \kappa^{\prime}\left\{u^{T} \dot{q}+v^{T} \dot{q}-\ddot{q}^{T} M(q) \dot{q}-d^{T}(q, \dot{q}) \dot{q}-e^{T}(q, z) \dot{q}\right\} \\
& +g(q, \dot{q}, \ddot{q})+r u^{T} \dot{q}
\end{aligned}
$$

上式右辺の \{\} 内は，式(1)の左辺と同じで制御対象の全パ ワー収支であるからエネルギ保存則を満たし常にゼロであ る．従って L の積分を最小化する条件は，式(2) も最小化す る. $\kappa$ は形の上では従来理論においてシステムの付帯条件を 考慮するために導入された随伴変数に相当するものである が，本理論では $\kappa$ は定数でよくその意味合いはパワー収支式 を制御則に反映させるための重み係数になる.上式のスカラ 一関数 $\mathrm{L}$ 構成は従来理論の展開に沿って評価関数に制御対 象の付帯条件を加えた形にしたが，随伴変数を持たないため 次式のようにL全体を評価関数の被積分関数と考えてもよい

$$
J=\int\left\{g(q, \dot{q}, \ddot{q})+r_{a} u^{T} \dot{q}+r_{b} P(q, \dot{q}, \ddot{q})\right\} d t
$$

ここで, $L=g(q, \dot{q}, \ddot{q})+r_{a} u^{\tau} \dot{q}+r_{h} P(q, \dot{q}, \ddot{q})$

上式中のPは $P(q, \dot{q}, \ddot{q})=-v^{T} \dot{q}+\ddot{q}^{T} M(q) \dot{q}+d^{T}(q, \dot{q}) \dot{q}+e^{T}(q, z) \dot{q}$ の上う に表されシステムのパワー収支式から制御入力を除いた項, $\mathrm{r}_{\mathrm{a}}, \mathrm{r}_{\mathrm{b}}$ は重み係数で正定值である.これより Jの最小化は性能 指標に加え制御入力エネルギとシステムの蓄積・散逸エネル ギを最小化することになり意味が明確である。

Jを最小化するための必要条件は次のオイラー・ポアソン の方程式 ${ }^{(7)}$ から得られる. $\partial \mathrm{L} / \partial \mathrm{u}=0$ は解を持たないため, 次式に制御に関するすべての情報が集約される.

$\frac{\partial L}{\partial q}-\frac{d}{d t}\left(\frac{\partial L}{\partial \dot{q}}\right)+\frac{d^{2}}{d t^{2}}\left(\frac{\partial L}{\partial \ddot{q}}\right)=0$

上式を積分し積分定数をぜロとすると次式になる.

$$
\int \frac{\partial L}{\partial q} d t-\frac{\partial L}{\partial \dot{q}}+\frac{d}{d t}\left(\frac{\partial L}{\partial \ddot{q}}\right)=0
$$

この積分定数は uの初期值に影響するが，一般にこのよう な不定積分の積分定数を決める条件は見当たらず, 特殊なケ 一スを除きゼロとすることで良い結果が得られている．具体 的には 3 章に適用例を示す。

式(5)を式(6)に代入すると次のようになる。

$$
\begin{aligned}
\int \frac{\partial g}{\partial q} d t & -\frac{\partial g}{\partial \dot{q}}+\frac{d}{d t}\left(\frac{\partial g}{\partial \ddot{q}}\right)+r_{a} u^{r} \\
+ & r_{h}\left\{\int \frac{\partial P}{\partial q} d t-\frac{\partial P}{\partial \dot{q}}+\frac{d}{d t}\left(\frac{\partial P}{\partial \ddot{q}}\right)\right\}=0
\end{aligned}
$$

式(6)は L を状態量で偏微分したものであるため, 式(7)の 意味はしの積分を最小化するために状態量がどう振舞うべき かを記述した運動方程式であって, 決して制御則ではない. 別の見方をすれば，Lの積分を最小化するための仮想的なあ るいは理想的なシステムの運動方程式を記述したものとも いえる。

式(7)の u 以外の項を右辺に移項すれば次式のように制御 則らしきものが得られ，これで制御するとかなりうまくいく ことがわかってきた.

$$
u^{T}=\frac{1}{r_{s}}\left[r_{b}\left\{\int \frac{\partial P}{\partial q} d t-\frac{\partial P}{\partial \dot{q}}+\frac{d}{d t}\left(\frac{\partial P}{\partial \ddot{q}}\right)\right\}+\int \frac{\partial g}{\partial q} d t-\frac{\partial g}{\partial \dot{q}}+\frac{d}{d t}\left(\frac{\partial g}{\partial \ddot{q}}\right)\right]
$$

式 (8) はこの理想的なシステムの入出力を逆にしたもので 形の上では制御則ではある。これが最適制御則ということに なれば, 関数 $\mathrm{P}$ や $\mathrm{g}$ がどのような複雑で非線形な形であろう と簡単な操作でほぼ自動的に求まるため適用分野も広く極 めて有益な手法となりうる。しかも式(7) は理想的なシステ 厶の微分方程式であり初期値を決めれば全てが確定するた め評価区間終端の境界条件は意味を失い, 2 点境界值問題を 扱う煩雑さがなくなる.

では一般論として理想的な特性の逆特性を制御則として 用いると最適制御則になるのであるうか, 実はここに閉ルー プ系の重要な性質が隠されているのである．隠されていると いうのは少し大袈裟で当たり前すぎて誰も注目しなかった という方が正しいかもしれない。一言でいえば閉ループ系に は方程式を解く性質があるのでこれを前面に出した手法に すればよいということである. 以下図 2 により具体的に説明 する。
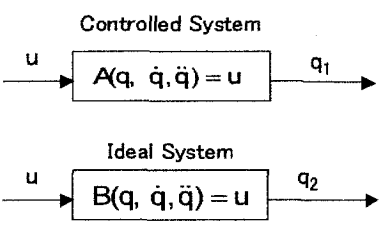

(a)

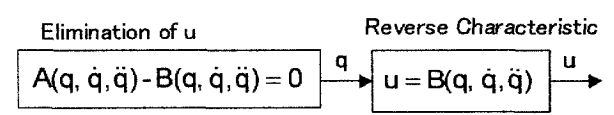

(b)

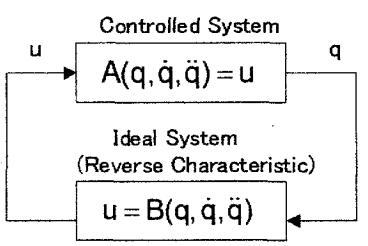

(c)

Fig. 2 Self Solving Mechanism of Closed Loop System

図 2(a)の上段のブロックはUを入力とする制御対象Aの微 分方程式(式(1)を速度べクトルで除したものに相当)を表し， 下段のブロックは同じuを入力とする理想特性B (式 (7)に相 当)を表している. 制御入力uによって制御対象をあたかも理

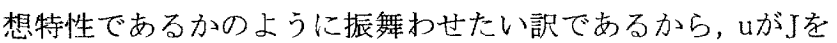


最小化する最適制御であれば，制御対象と理想特性に山を入 力した場合に双方の出力 $\mathrm{q}_{1}, \mathrm{q}_{2}$ が同じになるはずでありこれ が最適制御であるための必要条件となる.

このようなuを求めるためには, 図 2(b)のように制御対象 と理想特性の方程式を連立させてuを消去した微分方程式を 解いて q を求め, この q を理想特性の逆特性(式(8)に相当) に入力して求めることになる.

しかし，ここで，図 2 (c)のように理想特性の逆特性を用い て閉ループを構成すると，閉ループ系の性質により結果的に 前記連立方程式を解いたことになり，微分方程式を解かずに 最適な u を求めることができる. 閉ループ系であるため B の 逆特性出力と $\mathrm{A}$ 特性入力, $\mathrm{A}$ 特性出力と $\mathrm{B}$ の逆特性入力は同 一波形である。このことからシステム $\mathrm{A}$ とシステム $\mathrm{B}$ の順特 性とは単独で見た場合uに対する応答が同一になっていなけ ればならず,これよりシステム $\mathrm{A}$ とシステム B の順特性の連 立微分方程式の解 $\mathrm{q}$ が得られたということになる。

このように，閉ループ系の特性を利用しで制御対象を理 想特性に変換するという発想をべースにした制御理論”沙お そらく初めてであろうと思う。しかもシステム特性を変換す るだけであるから微分方程式を解く必要はなく, 制御システ ムの中で制御対象であるハードウエアの実際の運動とコン ピュータ内の理想運動方程式が協調して実時間で連立方程 式を解いてくれる. 式(8)の制御則には未実行の微積分項が 含まれているが, 全ての外力と状態量が検出あるいは推定で きることを前提にすればこれらの実時間での実行が可能で あり使い勝手の面では通常の状態フィードバック制御則と の差異はない.

\section{3. 本理論の適用例}

本制御理論によると, 式(4)の形の評価関数を用いる限り $\mathrm{g}$ やP がどんな複雑な関数形であるう容易に制御則が求まる. この点が, 複雑な散逸構造を有する系や性能の評価関数が複 雑な関数形で表示される場合の最適制御問題に対し極めて 有力な手法であることを明らかにする。

3.1 複雑な散逸構造を有する系への適用複雑な散逸構造 を有する系の代表として図 3 に示す自動車の運動を取り上げ る.このような簡略化されたモデルでも $\mathrm{xy}$ 方向の運動が連 成するため立派な非線形運動になるが，さらにタイヤの横す ベりによる横力は散逸エネルギとなりこのタイヤ横力特性 が車両の状態に俄存するため全体として極めて複雑な散逸 構造を形成する。このような複雑な散逸構造を持ったシステ ムの最適制御則を線形近似せず解析的に導いた例は今まで に皆無である．以下に車両モデルの運動方程式とタイヤ特性 式を示す。

$$
\begin{aligned}
& m\left(\dot{V}_{x}-V_{y} \dot{\varphi}\right)=\sum_{i=1}^{4} X \\
& m\left(\dot{V}_{y}+V_{x} \dot{\varphi}\right)=\sum_{r=1}^{4} Y_{i} \\
& I \ddot{\varphi}=\frac{d}{2}\left(X_{2}+X_{4}-X_{1}-X_{3}\right)+l_{r}\left(Y_{1}+Y_{2}\right)-l_{r}\left(Y_{3}+Y_{4}\right)+u
\end{aligned}
$$

ここで制御入力uは車両に加えられるヨーモーメントであり， 通常 4 輪の制駆動力制御装置により与えられる ${ }^{(8)}$. mは車両 質量, I はヨー慣性モーメント, $\mathrm{V}_{\mathrm{x}}, \mathrm{V}_{\mathrm{y}}, \dot{\varphi}, \mathrm{d}, \mathrm{I}_{\mathrm{f}}, \mathrm{I}_{\mathrm{r}}$ は図 3 に示 した速度や寸法である。

タイヤ横力 $S_{i}$ の表現式は各種あるが最も広く知られてい るFialaO式を用いる ${ }^{(9)}$.

$$
S_{r}=\mu W_{1}\left(\tau_{i}-\frac{1}{3} \tau_{i}^{2}+\frac{1}{27} \tau_{i}^{3}\right)
$$

$$
\begin{aligned}
\text { ここで, } \\
\tau_{i}=\frac{K}{\mu W_{t}} \tan \beta_{i} \\
\beta_{i}=\delta-\frac{V_{y}+l_{t} \dot{\varphi}}{V_{x}+(-1)^{\prime} \dot{\varphi} d / 2} \quad(i=1,2) \\
\beta_{i}=-\frac{V_{y}-l_{r} \dot{\varphi}}{V_{x}+(-1)^{\prime} \dot{\varphi} d / 2} \quad(i=3,4) \\
W_{i}=W_{s}-\frac{m}{2}\left(\dot{V}_{x}-V_{y} \dot{\varphi}\right) \frac{h}{l}+(-1)^{\prime} K_{f} m\left(\dot{V}_{y}+V_{x} \dot{\varphi}\right) \frac{h}{d} \quad(i=1,2) \\
W_{i}=W_{s}+\frac{m}{2}\left(\dot{V}_{x}-V_{y} \dot{\varphi}\right) \frac{h}{l}+(-1)^{\prime} K_{r} m\left(\dot{V}_{y}+V_{x} \dot{\varphi}\right) \frac{h}{d} \quad(i=3,4)
\end{aligned}
$$

である， $\mu$ は摩擦係数, W $W_{i}$ タイヤ荷重, Kはコーナリング パワー, $\beta_{\mathrm{i}}$ は横すべり角, $\delta$ は前輪舵角, $\mathrm{K}_{\mathrm{f}}, \mathrm{K}_{\mathrm{r}}$ は前後口ー 儿合成配分である。

式 (9)のX $X_{\mathrm{i}}$ は各タイヤのx方向発生力でドライバのアクセ ル操作と車両の駆動システムの構成で決まる． $\mathrm{Y}_{\mathrm{i}}$ は各タイヤ のy方向発生力で操舵しなければ上記のS $\mathrm{S}_{i}$ 等しい. 操舵が 有る場合は $\mathrm{S}_{\mathrm{i}}$ を, $\mathrm{y}$ 成分に分けて $X_{\mathrm{i}}, \mathrm{Y}_{\mathrm{i}}$ とする.

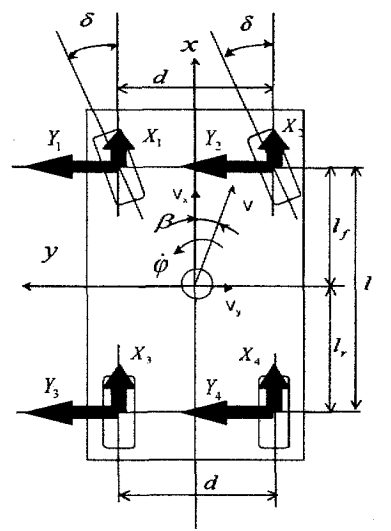

Fig. 3 Vehicle Model

ここで次の最適制御問題を考える.

問題 1 : ドライバが, 車速 $\mathrm{V}_{\mathrm{x}}$ で走行中に前輪舵角 $\delta$ の操舵を 行なった場合に, 次の評価関数了を最小化する制御則いを求め よ.

$$
J=\int\left\{r_{1}(\hat{\dot{\varphi}}-\dot{\varphi})^{2}+r_{a} u \dot{\varphi}+r_{b} P\right\} d t
$$

ここで $\hat{\dot{\varphi}}$ はヨーレートの目標值で舵角 $\delta に$ に比例した量, $r_{1}, r_{a}, r_{b}$ 重み係数である. 評価関数の意味は，小さい制御入 カエネルギでタイヤの散逸エネルギを小さく保って車両を 目標ヨーレートに追従させることである。

システムの蓄積・散逸パワーP 怡次式で与えられる.

$$
P=\left(m \dot{V}_{x} V_{x}+m \dot{V}_{y} V_{y}+I \ddot{\varphi} \dot{\varphi}\right)+\left(d_{1} V_{x}+d_{2} V_{y}+d_{3} \dot{\varphi}\right)
$$

ただし，

$$
\begin{aligned}
& d_{1}=m \dot{\varphi} V_{y}-\left(S_{1}+S_{2}\right) \sin \delta \\
& d_{2}=-m \dot{\varphi} V_{x}+\left(S_{1}+S_{2}\right) \cos \delta+S_{3}+S_{4} \\
& d_{3}=l_{f}\left(S_{1}+S_{2}\right) \cos \delta-l_{r}\left(S_{3}+S_{4}\right)+\frac{d}{2}\left(S_{1}-S_{2}\right) \sin \delta
\end{aligned}
$$

である。

式(13)のJの被積分関数を L としqの代わりに $\varphi$ を用いて 式(6)を適用すると，以下の最適制御則が求まる. 


$$
u_{o p t}=\frac{1}{r_{a}}\left\{-r_{b} \frac{\partial\left(d_{1} V_{x}+d_{2} V_{y}+d_{3} \dot{\varphi}\right)}{\partial \dot{\varphi}}+2 r_{i}(\hat{\dot{\varphi}}-\dot{\varphi})\right\}
$$

上式右辺の第 1 項は式(12) および $\mathrm{d}_{\mathrm{i}}, \beta_{\mathrm{i}}$ の定義式を用いる 々偏微分が可能で代数式にまで変形でき，これが求める解析 解となる. 従来の車雨運動の最適制御は式 (9) (12)に何ら かの線形化を施して状態フィードバック制御則を導くこと が行なわれていたが，このようにタイヤの非線形特性を直接 反映させた解析解による最適制御則を得たのは初めてであ る.

本制御と従来の比例制御による性能評価シミュレーショ ンの結果を図 4,5 に示す.

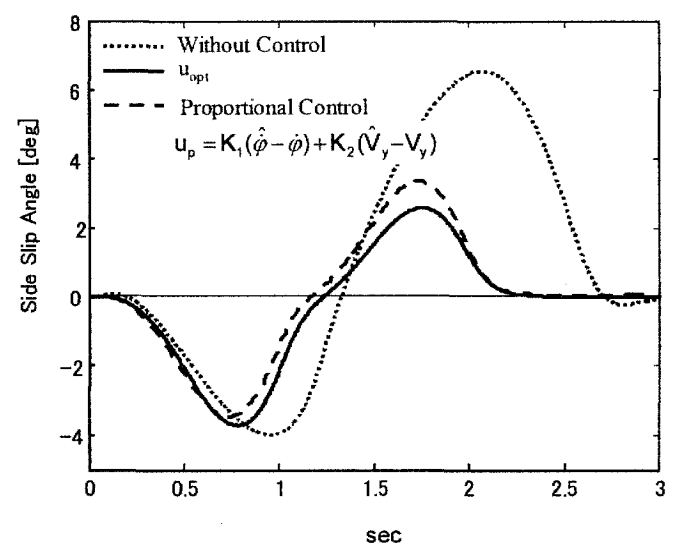

Fig. 4 Comparison of Controlled Characteristics

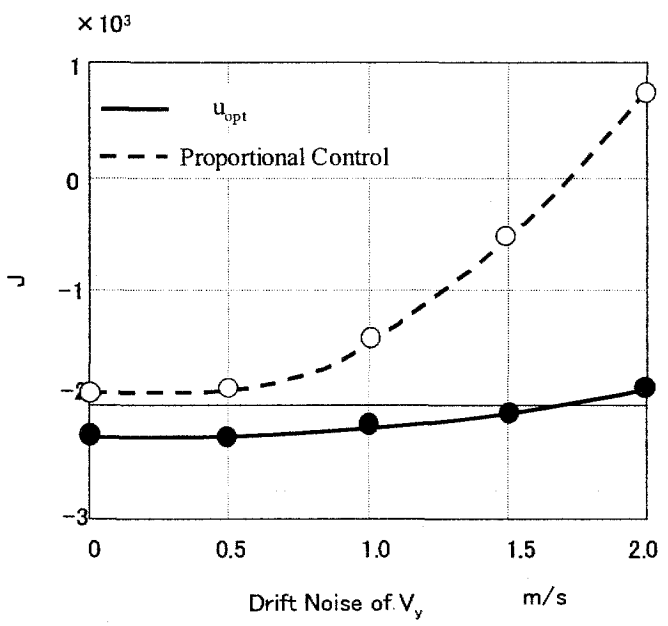

Fig. 5 Robustness to Drift Noise of Sideslip Angle

図 4 は，ドライバが時速 $100 \mathrm{~km} / \mathrm{h}$ で走行中に士120deg, 周 波数 $0.5 \mathrm{~Hz}$ の 1 周期分のハンドル操作 (急な車線変更に相当) を行なった場合の横す心゙り角を比較したものである。このよ うな厳しい車線変更では制駆動力制御のない車両では横す べり角が増大しスピンの危険性が増すのに対し制御するこ とで横すべりが減り安定性が増すことがわかる。しかし従来 制御と比べると性能的には大差ないように見える.今回の解 析解の一番のメリットは図 5 に示寸ロバスト性の改善に顕著 に現れている.車両の制御では横すべり角のフィードバック が必須であるが, この推定值にはドリフトが載りやすく十分 な制御ゲインを設定できないのが実態である. 本制御則は横 す心゙り角のヨーレートによる偏微分が主体であるためドリ フトの影響が小さく抜本的な改善策になりうる.

\section{2 性能の評価関数が複雑な形で表示される場合の最適制御}

問題 一般論として, 非ホロノミック系の制御は難しいと されており ${ }^{(10)}$ ，いきなり最適制御というよりシステムの特性 を活かした個別安定化制御の研究が多く行なわれている (11), (12). 非ホロノミック系の制御が難しい要因はシステムの 自由度に比べ制御入力の数が少ないことによるが，これを補 填するため従来の 2 次形式に替えて制御に有益な情報を評価 関数に盛り込むことが考えられる.しかし評価関数が複雑化 するため従来の方法で最適制御の解析解を得ることはさら に難しくなる.このような問題にも本手法は威力を発揮する. 性能の評価関数が複雑な最適制御問題として図 6 に示す水 中推進体について 1 個のアクチュエータで 3 次元空間の任意 の位置に移動する制御法を考える．運動方程式は次式になる。

$$
\begin{aligned}
& m(\dot{u}+q w-r v)+D_{x}=F_{x} \\
& m(\dot{v}+r u-p w)+D_{y}=0 \\
& m(\dot{w}+p v-q u)+D_{z}=0 \\
& I_{x} \dot{p}-\left(I_{y}-I_{z}\right) q r+D_{p}=\alpha F_{x} \\
& I_{y} \dot{q}-\left(I_{z}-I_{x}\right) r p+D_{q}=0 \\
& I_{z} \dot{r}-\left(I_{x}-I_{y}\right) p q+D_{r}=0
\end{aligned}
$$

ここで, u, v,w, p, q, rは図 6 に示す推進体固定の座標の各速 度成分, $D_{x}=C_{x}|u| u$ ただし $C_{x}$ は x 方向抵抗倸数, $\mathrm{D}_{\mathrm{y}}, \mathrm{D}_{\mathrm{z}}, \mathrm{D}_{\mathrm{p}}, \mathrm{D}_{\mathrm{q}}, \mathrm{D}_{\mathrm{r}}$ も同樣，mは質量， $I_{x}, I_{y}, I_{z}$ は慣性モーメント, $F_{x}$ はスクリュ 一による推力でこれが制御入力になり， $\alpha$ はスクリューを回 すモータのロール反カ係数である.

式(17)，(18)，(20)，(21) は加速度の拘束条件と考えると, これらは積分できないから非ホロノミック系とみなすこと ができ,これらの非ホロノミック拘束を積極的に活用して次 の最適制御問題を解析的に解いてみる.

問題 2 : 図 6 に示す 1 つアクチュエータを持つ水中推進体 が任意の位置から次の評価関数丁を最小化する即ち原点に移 動するための制御則 $\mathrm{F}_{x}$ を求めよ.

$$
J=X_{E}^{2}+Y_{E}^{2}+Z_{E}^{2}+\int\left\{r_{a}\left(F_{x} u+\alpha F_{x} p\right)+r_{b} P\right\} d t
$$

ここで, $X_{\mathrm{E}}, \mathrm{Y}_{\mathrm{E}}, Z_{\mathrm{E}}$ は推進体の絶対座標系における位置座標, $r_{1}$ は重み係数である.Jを積分型に書き直せば次式になる.

$$
J=\int\left\{2\left(\dot{X}_{E} X_{E}+\dot{Y}_{E} Y_{E}+\dot{Z}_{E} Z_{E}\right)+r_{a}\left(F_{x} u+\alpha F_{x} p\right)+r_{b} P\right\} d t
$$

絶対座標系の速度を推進体の状態量とオイラー角を用いて 書き換えると次式になる。

$$
\begin{aligned}
& \dot{X}_{E}=u l_{1}+v l_{2}+w l_{3} \\
& \dot{Y}_{E}=u m_{1}+v m_{2}+w m_{3} \\
& \dot{Z}_{E}=u n_{1}+v n_{2}+w n_{3}
\end{aligned}
$$

ここで,

$\left[\begin{array}{ccc}l_{1} & m_{1} & n_{1} \\ l_{2} & m_{2} & n_{2} \\ l_{3} & m_{3} & n_{3}\end{array}\right]=\left[\begin{array}{lll}\multicolumn{1}{c}{\cos \theta \cos \psi} & \multicolumn{1}{c}{\cos \theta \sin \psi} & -\sin \theta \\ -\cos \phi \sin \psi & \cos \phi \cos \psi & \\ +\sin \phi \sin \theta \cos \psi & +\sin \phi \sin \theta \sin \psi & \sin \phi \cos \theta \\ \sin \phi \sin \psi & -\sin \phi \cos \psi & \cos \phi \cos \theta \\ +\cos \phi \sin \theta \cos \psi & +\cos \phi \sin \theta \sin \psi & \end{array}\right]$ $\phi ， \theta ， \phi$ はオイラ一角である.これらオイラ一角は刻々計測 される $\mathrm{p}, \mathrm{q}, \mathrm{r}$ の值を用いて実時間で算出可能である. 以上の ようにこの性能評価関数は極めて複雑な形を有しているこ とがわかる。

システムの蓄積・散逸パワーP は次式で与えられる. 


$$
\begin{aligned}
P= & m(\dot{i n} u+\dot{w}+\dot{w} w)+\left(I_{x} \dot{p} p+I_{y} \dot{q} q+I_{z} \dot{r}\right)+\left(D_{x} u+D_{y} v+D_{z} w\right) \\
& +\left(D_{p} p+D_{q} q+D_{r}\right)
\end{aligned}
$$

式(22)のJの被積分関数を Lとし, 式(6)において $\dot{q}$ の代 わりに $\mathrm{u}, \mathrm{p}$ を用いると，以下の最適制御則が求まる.

$$
F_{x}=\frac{1}{r_{a}}\left\{\rho_{1} 3 r_{b} D_{x}-2 \rho_{1}\left(X_{E} l_{1}+Y_{E} m_{1}+Z_{E} n_{1}\right)+\rho_{2} \frac{3 r_{b} D_{p}}{\alpha}\right\}
$$

この場合散冕系のパワー式からは $\mathrm{x}, \mathrm{D}_{\mathrm{p}}$ に関する項しか得 られず, 制御のための情報の大半は性能の評価関数から得ら れていることがわかる.

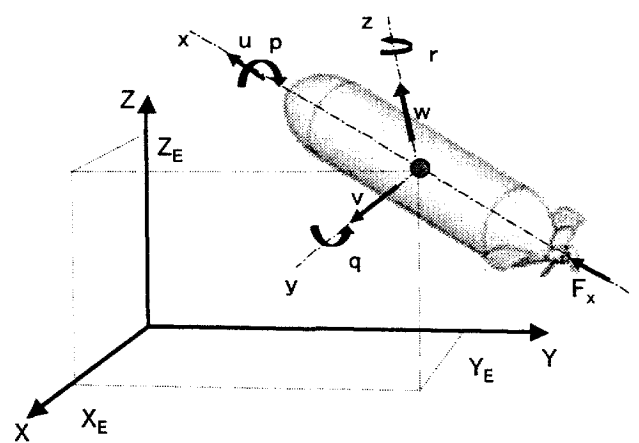

Fig. 6 Underwater Vehicle with Single Actuator

$\mathrm{X}_{\mathrm{E}}=10 \mathrm{~m}, \mathrm{Y}_{\mathrm{E}}=10 \mathrm{~m}, \mathrm{Z}_{\mathrm{E}}=10 \mathrm{~m}$ から原点を目指して移動制御した場 合のシミュレーション結果を図 7,8 に示す. 図 7 はアクチ ユエータ推力 $F_{x}$ の時間波形を, 図 8 は推進体重心点の軌跡を 示す.

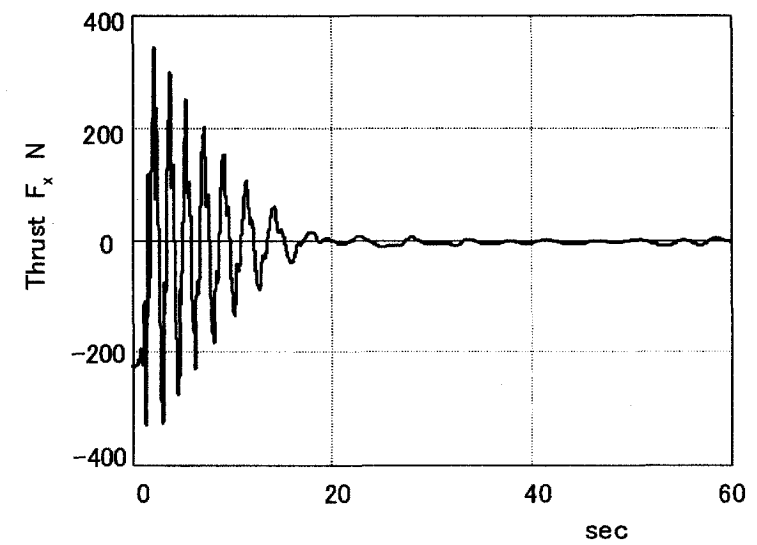

Fig. 7 Time Waveform of Thrust $F_{X}$

この結果より，1 つのアクチュエータ推力F $\mathrm{F}_{\mathrm{x}}$ を振動的に制 御するだけで任意の位置から原点へ移動が可能であること がわかる. 原点を特定座標に変更することは容易であるから， 結局この制御により 1 つのアクチュエータだけで 3 次元空間 を自在に移動できることになる. 従来の研究では 3 個のアク

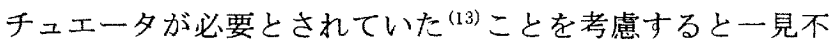
可能と思われることが可能になったわけであり，これが最適 制御研究の面白さである. 得られた制御則を吟味することに より推進の力学的根拠が明確になると考えられるが, 現段階 では, 式(17)，(18)，(20)，(21)で示されている遠心力, ジャ イロモーメント, 水の抵抗を合理的に活用しているという他 ない. 評価関数の創り方を工夫すればさらなる性能向上も可
能であり，一般論として非ホロノミック系の最適制御はこの 方向に開拓余地があると考えられる.

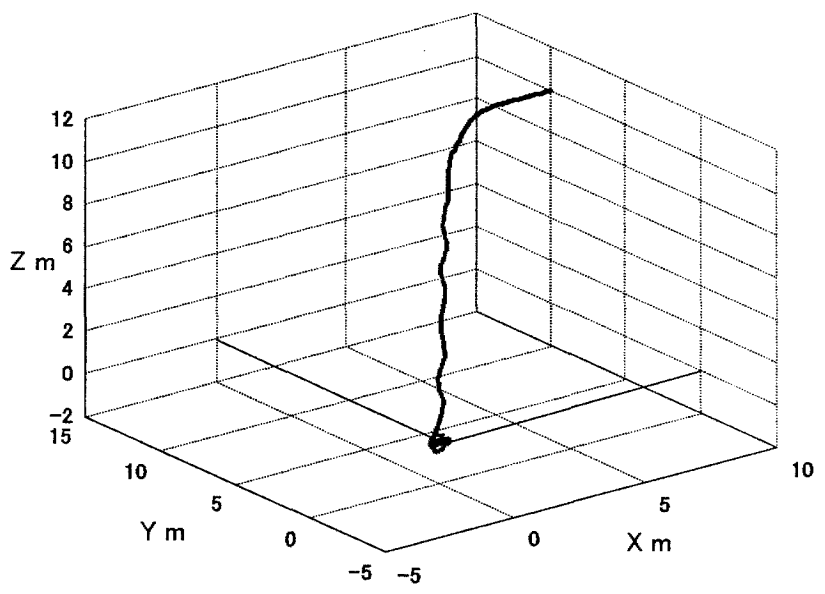

Fig. 8 Trajectory of Controlled Underwater Vehicle

\section{4. まとめ}

微分方程式を解かずに解析的な最適制御則が求められる 新しい手法を提案した。 これにより, 複雑な散逸構造を内蔵 するシステムや非ホロノミックな拘束を有するシステムの 実時間最適制御を行うことができる可能性がでてきたと考 える. 今回扱った非ホロノミック系は 1 階の微分方程式によ る拘束有する系であるが，今後は 2 階の微分方程式による 拘束を有する系やその他機械力学系一般に幅広く適用して 有效性を確認し制御理論における位置づけを明らかにして いきたい。

最適制御にこだわったのは，文献(4)の中の“最適制御の 面白さは常識では予想できない制御則が求まる可能性があ ること”という主旨の記述に共感したためであったが，実際 に研究をやってみてやはりその通りだと寒感する. 本論文は まだ荒削りで精緻な理論には程遠いが，最適制御理論として 新しい展開の可能性を持つと考えられるため, 数学的に厳密 な理論にまとめ上げるべく努力していきたい.

\section{参考文献}

（1） ポントリャーギン他, 関根智明訳 : 最適過程の数学的理 論, 文一総合出版 (1967)

（2）嘉納秀明,最適制御問題一変分法と $\mathrm{H}^{\infty}$ 制御および粘性解 -, 計測と制御 Vol. 36, No. 11 (1997), pp. 768-775.

（3）福島直人, 制御対象のエネルギ収支に着目した機械力 学系の最適制御，日本機械学会論文集 (C 編) Vol. 72 , No. 722 (2006), pp. 36-44.

（4）加藤寛一郎, 工学的最適制御, 東京大学出版会 (1988)

（5）大塚敏之, 非線形最適フィードバック制御のための実 時間最適化手法, 計測と制御, 36-11 (1997), pp. 776-781.

(6) 有本卓, 新版ロボットの力学と制御, 朝倉書店 (2002)

（7）L.E.エルスゴルツ, 瀬川富士訳 : 科学者・技術者のため の変分法, ブレイン図書出版 (1972)

(8) Anton T. van Zanten, Rainer Erhardt, Georg Pfaff, VDC, The Vehicle Dynamics Control System of Bosch, SAE paper 950759 (1995)

（9）安部正人，自動車の運動之制御，山海堂 (1992)

（10）中村仁彦，非ホロノミック系制御研究の展望，計测と 制御 Vol. 36, No. 6 (1997), pp. 384-389. 
（11）三平満司，非ホロノミック系のフィードバック制御， 計測と制御 Vol. 36, No. 6(1997), pp. 396-403.

（12）藤本健治, ハミルトニアンシステムの制御, 計測と制 御 Vol. 39, No. 2 (2000), pp. 99-104.
(13) K. Y. Pettersen, O. Egeland, Position and Attitude Control of an Underactuated Autonomous Underwater Vehicle, Proceedings of the 35th Conference on Decision and Control, IEEE (1996), pp. 987-991. 